\title{
Detection of Salmonella enteritidis, typhi and typhimurium in foods by multiplex PCR in children hospital
}

\author{
Shima Nosraty ${ }^{1}$, Fatemeh Fallah²*, Azar Sabokbar', Mehrooz Dezfoolyan', Saadat Adabian, Narges Esmaeilnejad ${ }^{1}$ \\ From First International Science Symposium on HIV and Infectious Diseases (HIV SCIENCE 2012) \\ Chennai, India. 20-22 January 2012
}

\section{Background}

Food-borne illnesses have high prevalence in the world, which are caused by consumption of water or food contaminated. Nowadays, involvement caused by Salmonella bacterium, serotype enteritidis and typhimurium are the major infection all around the world. So the purpose of this study is detection of Salmonella enteritidis, typhi and typhimurium in different kinds of foods by multiplex PCR method.

\section{Methods}

The study was conducted on 170 samples of food products including, milk, beef, poultry, salad dressing and 80 samples in contact with food items such as knives, cutting boards and the hands of personnel working in a hospital's kitchen. After collecting the samples, the standard diagnostic method for detection of bacteria were performed and after extracting the DNA, the multiplex PCR method has been used for determination of Salmonella serotypes.

\section{Results}

From all of the tested food samples (170), 1.7\% of Salmonella contamination has observed that $1.1 \%$ related to typhimurium and $0.6 \%$ related to Salmonella enteritidis that had separated from beef, and during the tests conducted on samples that were in contact with food items, Salmonella contamination was not detected.

\section{Conclusion}

Results indicated that, quality control of food products in processing and production stages observing hygiene

\footnotetext{
* Correspondence: fallah@pirc.ir

${ }^{2}$ Pediatric Infectious Research Center, Shahid Beheshti Medical University, Tehran, Iran

Full list of author information is available at the end of the article
}

issues are critically important in preventing food-borne diseases. And also the methods like molecular diagnostic such as multiplex PCR besides the cultivation of bacteria and other microbes can be helpful in diagnostic confirmation.

\section{Author details \\ ${ }^{1}$ Karaj Branch, Islamic Azad University, Karaj, Iran. ${ }^{2}$ Pediatric Infectious Research Center, Shahid Beheshti Medical University, Tehran, Iran.}

Published: 4 May 2012

doi:10.1186/1471-2334-12-S1-P95

Cite this article as: Nosraty et al:: Detection of Salmonella enteritidis, typhi and typhimurium in foods by multiplex PCR in children hospital. BMC Infectious Diseases 2012 12(Suppl 1):P95.

\footnotetext{
Submit your next manuscript to BioMed Central and take full advantage of:

- Convenient online submission

- Thorough peer review

- No space constraints or color figure charges

- Immediate publication on acceptance

- Inclusion in PubMed, CAS, Scopus and Google Scholar

- Research which is freely available for redistribution

Submit your manuscript at www.biomedcentral.com/submit
}

C Biomed Central

C 2012 Nosraty et al; licensee BioMed Central Ltd. This is an Open Access article distributed under the terms of the Creative Commons Attribution License (http://creativecommons.org/licenses/by/2.0), which permits unrestricted use, distribution, and reproduction in any medium, provided the original work is properly cited. 